Sains Malaysiana 49(3)(2020): 713-719

http://dx.doi.org/10.17576/jsm-2020-4903-26

\title{
The Risk Measurement of Horticultural Price: A Comparison Based on Financial Access in West Java, Indonesia
}

(Pengiraan Risiko Harga Hortikultur: Suatu Perbandingan berdasarkan Akses Pembiayaan di Jawa Barat, Indonesia)

\author{
ELIANA WULANDARI*, DIKA SUPYANDI \& ERNAH
}

\begin{abstract}
Access to finance has been an important issue in minimizing the risk in agricultural prices. Farmers in Indonesia can access finance from different financial sources, including from banks, micro finance institutions (MFIs), farmers' associations, traders, agricultural input kiosks, family, and friends. This research was aimed to investigate the difference of price risk between farmers who had access to finance from different financial providers and those who did not, and to analyze the price risk and its relation to some socioeconomic variables. A survey was conducted to collect data from selected horticultural farmers, i.e. potato and banana farmers at the center of potato and banana production in West Java. The price risk was analyzed using 25th percentile and coefficient of variation. Moreover, the data were analyzed using independent t-test to see the difference of the risk between the groups of farmers, and censored regression model to see the relation between price risk and some socioeconomic variables. The results show that farmers who had access to financial sources from MFIs, farmers' associations, traders and from other financial sources had a lower price risk of banana compared to the farmers who did not have access to finance from those financial providers. The results also show that farmers having access to finance from traders had lower risk in terms of the price distribution. The findings suggest the need to enhance financial access from MFIs, farmers'associations, and traders since those finance providers seem to have potency to minimize the farmers' risk on price.
\end{abstract}

Keywords: Access to finance; horticulture; price risk

ABSTRAK

Akses kepada pembiayaan merupakan satu isu penting dalam meminimumkan risiko harga pertanian. Petani di Indonesia dapat mengakses pembiayaan daripada pelbagai sumber pembiayaan, termasuk bank, institusi pembiayaan mikro (MFI), persatuan petani, pedagang, kios input pertanian, keluarga dan rakan. Kajian ini bertujuan untuk mengkaji perbezaan risiko harga antara petani yang mempunyai akses terhadap pembiayaan daripada penyedia pembiayaan dan mereka yang tidak serta menganalisis risiko harga dan kaitannya dengan beberapa pemboleh ubah sosioekonomi. Suatu kajian telah dijalankan untuk mengumpul data daripada petani hortikultur terpilih, iaitu petani kentang dan pisang di pusat pengeluaran kentang dan pisang di Jawa Barat. Risiko harga dianalisis menggunakan persentil ke-25 dan koefisien variasi. Tambahan pula, data dianalisis menggunakan uji-t bebas untuk melihat perbezaan risiko antara kelompok petani dan model regresi yang disensor untuk melihat hubungan antara risiko harga dan beberapa pemboleh ubah sosioekonomi. Hasil kajian menunjukkan bahawa petani yang mempunyai akses kepada sumber pembiayaan daripada MFI, persatuan petani, pedagang dan sumber pembiayaan lain mempunyai risiko harga pisang yang lebih rendah berbanding dengan petani yang tidak mendapat akses daripada penyedia pembiayaan tersebut. Hasil kajian juga menunjukkan bahawa petani yang mendapat akses kepada pedagang mempunyai risiko yang lebih rendah daripada segi distribusi harga. Hasil kajian menunjukkan perlunya meningkatkan akses pembiayaan daripada MFI, persatuan petani dan pedagang kerana penyedia pembiayaan tersebut mempunyai potensi untuk meminimumkan risiko harga petani.

Kata kunci: Akses kepada pembiayaan; hortikultur; risiko harga

\section{INTRODUCTION}

Risks in agriculture have long been discussed by experts in agriculture. One of the risks faced by farmers is the price fluctuation of agricultural commodities (Rachman 1997), which can lead to high price when the farmers face low production and low price when they have high production (Anwarudin et al. 2015). The price fluctuation can be because of weather and pest and disease attacks (Anwarudin et al. 2015), which can cause lower production and farmers' demotivation in involving in agriculture. Another study has shown that price risk significantly influences farmers' consumption, supply of labor and input decision (Saha 1994).

Many studies have reported the price risk of horticultural commodities in Indonesia. The issue of horticultural commodities such as red chili, red onion, 
tomatoes and potatoes is important in the Indonesian food supply needs because of frequent price fluctuations (Kaburuan et al. 2019). Suherman et al. (2017) has indicated that red chili farmers often faced enormous losses because of the price fluctuation of red chili, which was very high in some time then went down drastically. Furthermore, Hariyani et al. (2017) noted that horticultural prices, including red chili, fluctuated especially in the beginning of rainy season, in which the price risk became more volatile and difficult to control by farmers. Moreover, the price fluctuation of shallot farm in Central Sulawesi, Indonesia has caused farmers reducing inputs utilization (Erny et al. 2019).

The problem of price risk may be covered by having access to finance. The provision of access to finance is one of the key strategies in the development of sustainable agriculture program, which potentially increases farmers' income (Adiprasetyo et al. 2015). Furthermore, finance benefits economic growth, which then can raise the level of income (Claessens 2006). Having access to credit increases the opportunity of farmers on productive investment, which can improve agricultural production leading to stable price (Gebrehiwot \& Van der Veen 2013).

In general, finance can be accessed from many financial sources such as from banks, micro finance institutions (MFIs), government through farmers' associations, traders, agricultural input kiosks and other financial sources (Wulandari et al. 2017). Wulandari et al. (2017) showed that banks and MFIs have provided finance for farmers in the form of credit, while government has provided in-kind finance (non-cash finance) such as agricultural inputs and harvesting tools through farmers' association. Similarly, traders or buyers have provided finance for farmers in the form of in-kind finance. The study further showed that farmers can access finance from agricultural input kiosks in the form of the flexibility of agricultural input payment, in which farmers can pay agricultural inputs several days after the purchase or after harvesting.

Study on price risk has been an important issue especially in agricultural production (Chembezi 1991), which can affect to farmers' decisions (Ogurtsov et al. 2009; Saha 1994). Despite the importance of discussing price risk in agriculture, to the best of authors' knowledge, the literature of price risk that relates to access to finance from different financial sources has not been available yet. In this case, the objective of this study was to analyze the difference of price risk between two farmers' groups, i.e. farmers who obtained finance from different financial providers and farmers who did not obtain.

This study focuses on selected horticultural farmers, i.e. potato and banana since those products have been identified as important products for Indonesia (Agricultural Ministry of Indonesia 2011). Hasni (2017) noted that today's healthy lifestyle tends to be vegetarianism worldwide, which affects higher demand on horticultural products, especially fruits and vegetables. The literature further shows that fruits and vegetables have contributed to export income for Indonesia, including banana and potato.

\section{MATERIALS AND METHODS}

The method used in this study was a cross-sectional study survey using structured individual interview questionnaire. Contacting respondents using questionnaire is the best mean in a sampling survey (Ling et al. 2014). Data were collected from April to September 2018 especially from 120 potato and banana farmers at the center of potato and banana production in West Java, Indonesia. This study applied simple random sampling. First, the study areas were determined based on the highest production of potato and banana in West Java. Amongst the provinces in West Java, the district of Garut was the highest potato production and Cianjur and Ciamis districts for banana (BPS 2017a). Both Cianjur and Ciamis were taken as the study areas since those two areas did not have a significant difference on the banana production. Afterwards, two sub-districts were determined for each district based on the highest production of the selected products. The data of BPS (2017b) reported that Pasirwangi and Cikajang subdistricts were the highest potato production in Garut, while the highest banana production in Cianjur was the subdistricts of Cibeber and Sukaresmi, and the sub-districts of Lakbok and Purwadadi for Ciamis.

The data used in this study were the data of potato and banana prices obtained by each farmer during the years 2015 to 2017 . Furthermore, access to finance from different financial sources was also enquired of the farmers during those three years, including the access to finance from banks, micro finance institutions, farmers' associations, traders, agricultural input kiosks, and from family and friends.

The price risk was analyzed using risk measures, i.e. 25 th percentile and coefficient of variation. The first measure was used to analyze the risk in terms of the minimal price, while the latter was used to measure the risk in terms of the variability of price distribution faced by the farmers. The formula of percentile (Bluman 2009) is:

$$
\text { Percentile }=\frac{(\text { number of values below } X)+0.5}{\text { total number of values }} .100 \%
$$

Coefficient of variation is calculated by dividing the standard deviation by the mean (Hardaker et al. 2015). The formula of coefficient of variation used in this study is:

$$
\mathrm{CV}=\frac{\sigma}{\mathrm{R}}
$$

where $\mathrm{CV}$ is the coefficient of variation; $\sigma$ is standard deviation (IDR per $\mathrm{kg}$ ); and $\mathrm{R}$ is the mean of price (IDR per $\mathrm{kg}$ ). IDR is the abbreviation of Indonesian Rupiah, in 
which the average of 1 US\$ equal to IDR 14,710 in 2018 (BPS 2019). Next, independent t-test was carried out to analyze the difference of price risk between two farmers' groups, i.e. farmers who obtained finance from different finance providers and those who did not have access. Farmers' access to finance in this study was analyzed in terms of access to credit from banks (bank) and micro finance institutions (MFI), in-kind finance (non-cash finance) from farmers' associations and traders, flexible payment of inputs from agricultural input kiosks and other finance sources such as from family and friends. The formula of t-test (Bluman 2009) is:

$$
t=\frac{\left(\bar{X}_{1}-\bar{X}_{2}\right)-\left(\mu_{1}-\mu_{2}\right)}{\sqrt{\frac{s_{1}^{2}}{n_{1}}+\frac{s_{2}^{2}}{n_{2}}}}
$$

where $t$ is the different test; $\overline{\mathrm{x}}_{1}-\overline{\mathrm{x}}_{2}$ is the observed difference between sample means; $\mu_{1}-\mu_{2}$ is the equal to zero when population means have no difference; and $\sqrt{s_{1}^{2} / n_{1}+s_{2}^{2} / n_{2}}$ is the standard error of the difference.

Furthermore, censored regression model was performed to analyze the relation between price risk and some socioeconomic variables including age, gender, educational background and farming experience. The formula of the censored regression model (Verbeek 2004) is:

$$
y^{*}{ }_{i}=x^{\prime} \beta+\varepsilon_{i}, \quad i=1,2,3, \ldots, N
$$

Following the formula, the censored regression model used in this study is:

$$
\begin{aligned}
& \mathrm{y}_{\mathrm{i}}^{*}=\beta_{1}+\beta_{2} \text { age }+\beta_{3} \text { gender }+\beta_{4} \text { education } \\
& +\beta_{5} \text { experience }+\varepsilon_{\mathrm{i}}
\end{aligned}
$$

where the dependent variable $\mathrm{y}_{\mathrm{i}}{ }_{\mathrm{i}}$ is the measurement of price risk. The independent variables $\left(\mathrm{x}_{\mathrm{i}}\right)$ are socioeconomic factors including age, gender, education, and farming experience. Age was measured in years; gender is a dummy variable ( 0 for woman and 1 for man); educational background was measured in the years of formal education accomplished by the farmers; farming experience is the years of farmers in farming management. Those socioeconomic variables are expected to have relation to the price risk. Hartati (2007) found that age and farming experience affect farmers' behavior in dealing with agricultural risk. Furthermore, age affects physical ability of farmers in managing their farms, while education and farming experience relates to technology adoption and better decision in managing their farms (Kurniati 2015).

The problem of homoscedasticity was checked using the Breusch-Pagan test. Furthermore, the multicollinearity problem for each variable was also checked using the Variance Inflation Factors (VIF). There was not any multicollinearity problem found in all socioeconomic variables used in the model following the observation of Rook et al. (1990) that multicollinearity problem does not exist when the VIFs of all variables are below 10.

\section{RESULTS AND DISCUSSION}

Table 1 presents the descriptive statistics of the respondents including socioeconomic characteristics and farmers' access to finance from different financial sources. Table 1 shows that, on average, potato farmers were younger than banana farmers. Furthermore, most of the respondents were male, both for potato and banana farmers. With regard to educational background, overall, the farmers had seven years in educational background and 21 years of farming experience.

Figures 1 and 2 present the access of farmers to finance from different sources of finance. Figure 1 shows that most of the farmers had access to finance from traders. Figure 1 also shows that not that many farmers had access to formal finance sources such as from banks and MFIs; only $6 \%$ of farmers had access to credit from bank, and $3 \%$ of the farmers had obtained credit from MFIs.

With regard to the farmers' access of finance per crop, Figure 2 shows that the majority of farmers, both for potato and banana farmers, had access to finance from traders. Regarding access to formal financial sources such as banks and MFIs, only $4 \%$ of potato farmers and $13 \%$ of banana farmers had access to those sources of finance.

The results of risk measurement per crop are presented in Figures 3 and 4. Figure 3 shows the result of risk measurement in terms of 25 th percentile, while Figure 4 presents the result of risk measurement in terms of coefficient of variation. Figure 3 shows that potato farmers having access to finance from government through farmers' association have the highest value of the 25 th percentile. This result indicates that the potato farmers having access to government financing have the highest minimal price of potato. Figure 3 further shows that banana farmers who

TABLE 1. The descriptive statistics of the respondent

\begin{tabular}{lccc}
\hline Variable & Potato & Banana & Overall \\
\hline Age & 43 & 54 & 49 \\
Gender & 0.88 & 0.97 & 0.92 \\
Education & 8 & 7 & 7 \\
Farming experience & 18 & 24 & 21 \\
\hline
\end{tabular}




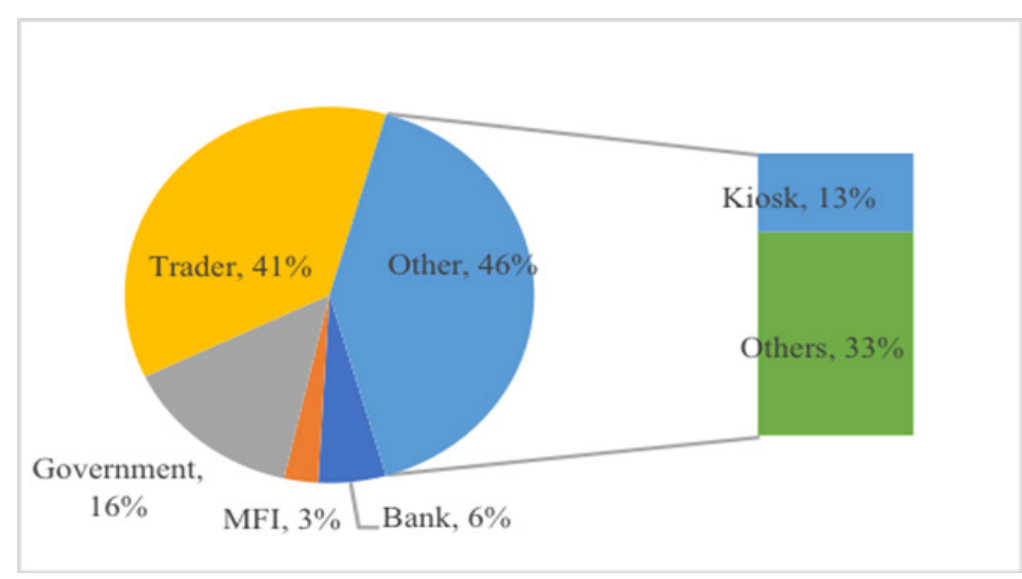

FIGURE 1. Farmers' access to finance

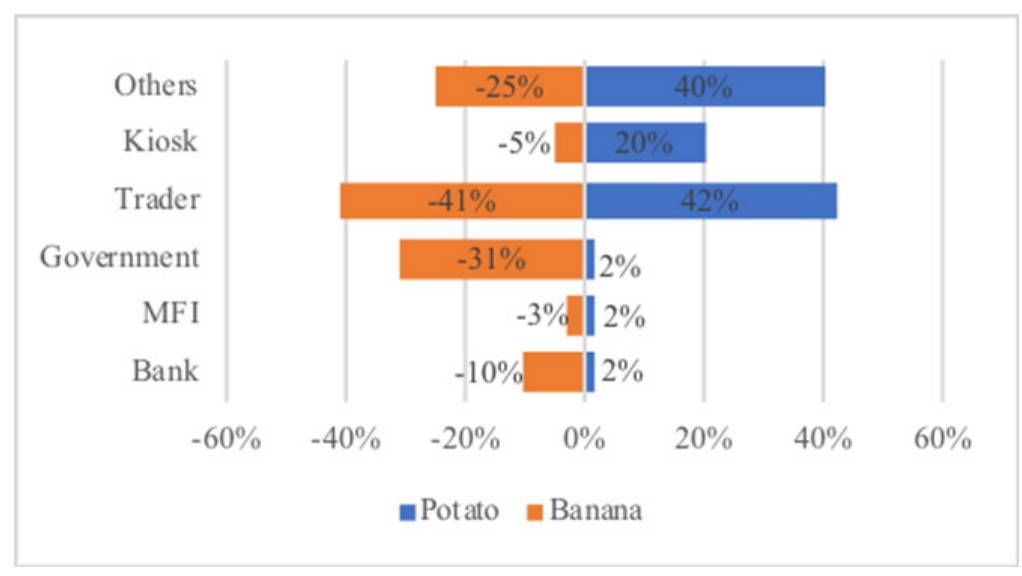

FIGURE 2. The farmers' access to finance per crop

had access to finance from MFIs have the highest value of the 25 th percentile. This result indicates that the banana farmers having access to MFIs financing have the highest minimal price of banana.

According to the results of the coefficient of variation, Figure 4 shows that potato farmers who had access to finance from banks have the highest value of the coefficient of variation. This result indicates that the potato farmers having access to banks have the highest variation of potato price. Figure 4 further shows that banana farmers who obtained access to government financing and the other financial sources such as family and friends have the highest value of the coefficient of variation. This result indicates that the banana farmers having access to those financial sources have the highest variation of banana price.

The result of different tests is presented in Table 2. In general, the significant difference exists only for access to finance from traders with the coefficient of variation for potato farmers, while for banana farmers, the difference exists for 25th percentile with access to finance from financial providers including from MFIs, government through farmers' associations, traders and from other financial sources, such as from family and friends.
With regard to the 25th percentile, farmers having finance from MFIs, government through farmers' associations, traders and from other financial sources have a significant difference of banana price risk from the farmers who did not have access to those financial providers. The results indicate that the farmers who obtained finance from MFIs, government through farmers' associations, traders and from other financial sources have a higher 25th percentile compared to those with no access, implying that farmers having access to finance from MFIs, government through farmers' associations, traders and from other financial sources have a higher minimal price of banana compared to the farmers who did not have access to finance from those financial providers. Previous studies have found that credit from MFIs can be used to buy inputs with higher quantities and better quality (Girabi \& Mwakaje 2013); which might affect to more robust yield and lead to more stable price. Furthermore, agricultural input provision to the member of association (Lamprinopoulou et al. 2006) and farmers having contracts with traders (Schipmann \& Qaim 2011) might also improve production and lead to more stable prices. Moreover, agricultural credit positively affects productivity, which may lead to more stable price (Wicaksono 2014). 


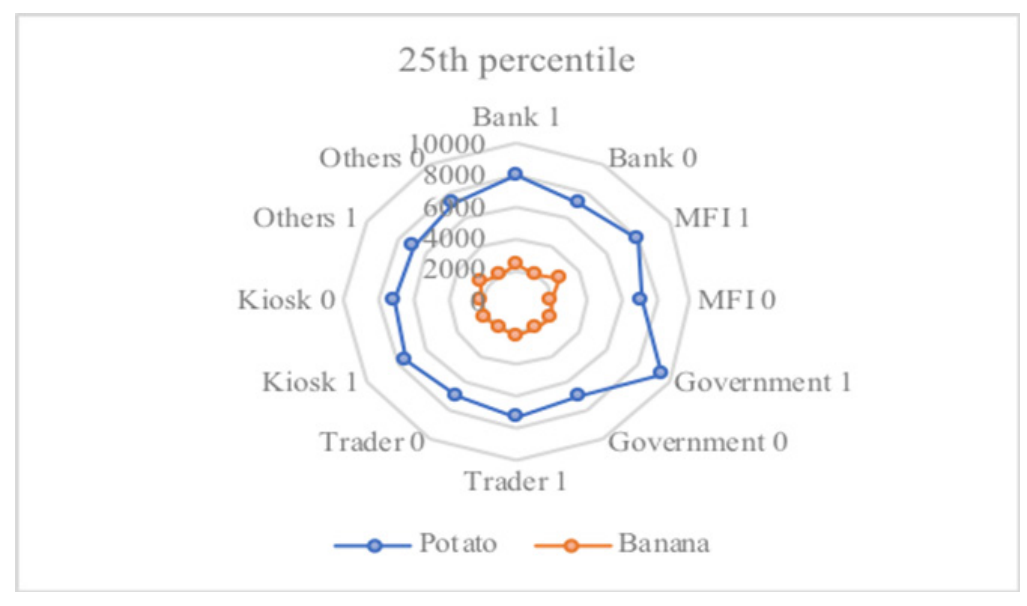

FIGURE 3. The risk measurement of 25th percentile based on financial accessibility

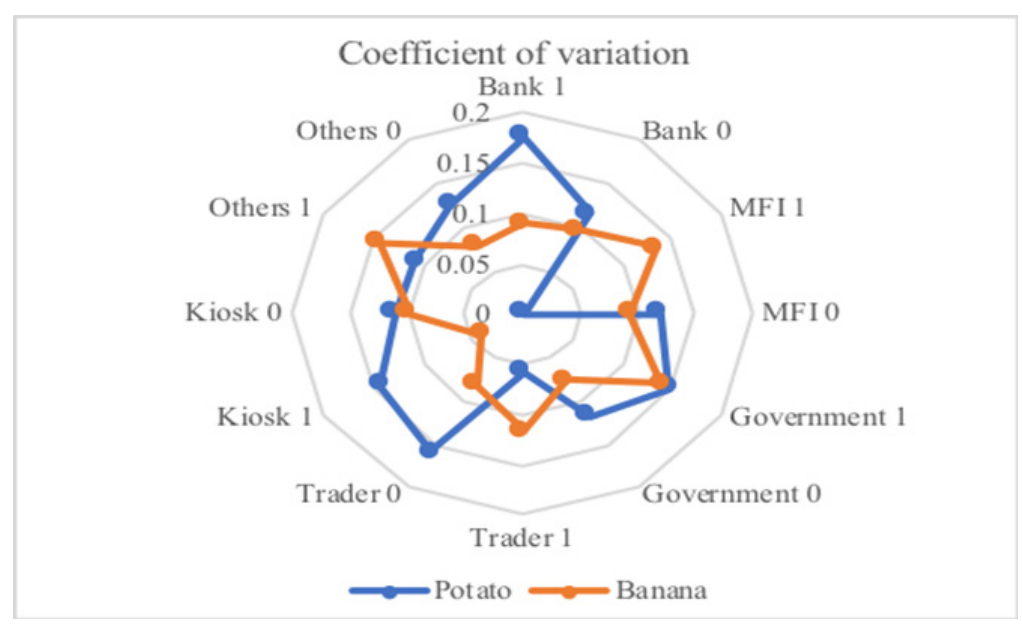

FIGURE 4. The risk measurement of coefficient of variation based on financial accessibility

TABLE 2. The mean values of the variables for the different tests

\begin{tabular}{|c|c|c|c|c|c|}
\hline \multirow[t]{2}{*}{ Sources of Finance ${ }^{\mathrm{a}}$} & & \multicolumn{2}{|c|}{ Potato } & \multicolumn{2}{|c|}{ Banana } \\
\hline & & 25 th percentile & $\mathrm{CV}$ & 25 th percentile & $\mathrm{CV}$ \\
\hline \multirow[t]{2}{*}{ Bank } & 0 & 7098 & 0.12 & 2020 & 0.10 \\
\hline & 1 & 8000 & 0.18 & 2292 & 0.09 \\
\hline \multirow[t]{2}{*}{ MFI } & 0 & 7098 & 0.12 & $2023^{\mathrm{b}}$ & 0.09 \\
\hline & 1 & 8000 & 0.00 & $2750^{\mathrm{b}}$ & 0.13 \\
\hline \multirow[t]{2}{*}{ Government } & 0 & 7073 & 0.12 & $1944^{\mathrm{b}}$ & 0.08 \\
\hline & 1 & 9500 & 0.15 & $2283^{\mathrm{b}}$ & 0.14 \\
\hline \multirow[t]{2}{*}{ Trader } & 0 & 6965 & $0.16^{\mathrm{b}}$ & $1884^{\mathrm{b}}$ & 0.08 \\
\hline & 1 & 7325 & $0.06^{\mathrm{b}}$ & $2285^{\mathrm{b}}$ & 0.12 \\
\hline \multirow[t]{2}{*}{ Kiosk } & 0 & 7064 & 0.11 & 2046 & 0.10 \\
\hline & 1 & 7310 & 0.14 & 2083 & 0.04 \\
\hline \multirow[t]{2}{*}{ Others } & 0 & 7263 & 0.12 & $1936^{\mathrm{b}}$ & 0.08 \\
\hline & 1 & 6895 & 0.11 & $2373^{\mathrm{b}}$ & 0.14 \\
\hline
\end{tabular}

a 0 : did not have access to; 1 : had access to

${ }^{\mathrm{b}}$ Significantly different at 5 percent level 
TABLE 3. The mean values of the variables for the censored regression model

\begin{tabular}{|c|c|c|c|c|}
\hline \multirow[t]{2}{*}{ Variable } & \multicolumn{2}{|c|}{ Coefficient of variation } & \multicolumn{2}{|c|}{25 th percentile } \\
\hline & Potato & Banana & Potato & Banana \\
\hline Age & 0.003 & -0.004 & -0.435 & 6.854 \\
\hline Gender & $0.104^{b}$ & $-0.101^{\mathrm{a}}$ & -164.353 & -299.106 \\
\hline Educational background & -0.002 & -0.024 & $148.173^{b}$ & -55.326 \\
\hline Farming experience & -0.003 & -0.003 & 16.817 & -1.732 \\
\hline Constanta & -0.088 & 0.563 & 5845.85 & 2371.524 \\
\hline
\end{tabular}

a,b Significantly related at 5 and 10 percent level, respectively

Table 2 also shows that, in terms of coefficient variation, farmers who obtained finance from traders significantly differed from farmers who had no access to finance from this financial source. The result indicates a lower coefficient of variation for farmers with access to finance from other finance sources, implying that farmers having access to finance from traders have lower risk in terms of the price distribution. Most of the farmers have cash flow problems during the periods of planting and growing (Bozoglu \& Ceyhan 2007), therefore, finance from traders might help farmers in improving their production and hence lead to more stable prices.

The result of censored regression model is presented in Table 3, which shows that, with regard to gender, male potato farmers have a higher coefficient of variation compared to female potato farmers implying that male potato farmers have a higher price risk. By contrast, male banana farmers have a lower coefficient of variation compared to the females, implying that male potato farmers have a lower price risk.

Table 3 also shows that more educated potato farmers have a higher 25 th percentile. This indicates that more educated potato farmers have a higher minimal price. Adiprasetyo et al. (2015) found that more educated farmers earned better price because they directly sold their products to consumer. Hamzah et al. (2016) studied on healthy Malay adults reported that educational level related to cognitive performance. The relation thus may also affect the thinking and effort in minimizing production risk.

\section{CONCLUSION}

This study addresses the issue of access to finance in minimizing the risk of agricultural price. The objective of this study was to analyze the difference of price risk between farmers who obtained finance from different finance providers and farmers who did not obtain the finance. This study also analyzed the relation between the price risk and some socioeconomic variables such as age, gender, educational background and farming experience. Data were gathered from 120 potato and banana farmers at the center of potato and banana production in West Java, Indonesia. The results show that farmers having access to finance from MFIs, government through farmers' associations, traders and from other financial sources have a higher minimal price of banana, which indicates a lower risk of price compared to the farmers with no access to finance from those financial providers. The results also show that farmers having access to finance from traders have lower risk in terms of the price distribution. Furthermore, gender has a significant relation to the price risk of potato and banana farmers in terms of the price distribution measurement, while education significantly associates with the price risk of potato farmers in terms of the measurement of minimal price risk.

The findings suggest the need to enhance financial access from MFIs, government through farmers' associations, and traders since those finance providers seem to have potency to minimize the farmers' risk on price. Encouraging farmers to have contracts with traders would give benefit for farmers to minimize price risk as Astuti et al. (2013) and Slamet et al. (2017) reported that contract gave some benefits to farmers including a more certain and better price. Furthermore, it is important to motivate farmers to join to a farmers' group in order to be able to have access to financial program from government distributed through a farmers' association (Wulandari et al. 2017).

\section{ACKNOWLEDGEMENTS}

The authors gratefully acknowledge all the farmers for taking part in this study. Furthermore, the authors greatly appreciate the directorate of research, community service and innovation of Universitas Padjadjaran for financial support for this study.

\section{REFERENCES}

Adiprasetyo, T., Sukisno, Setyowati, N., Ginting, S. \& Handajaningsih, M. 2015. The prospect of horticultural organic farming as sustainable agricultural practice for reducing poverty: The case in Bengkulu City, Indonesia. International Journal on Advanced Science Engineering Information Technology 5(6): 402-406.

Agricultural Ministry of Indonesia. 2011. Pedoman Teknis Pelaksanaan Pengembangan Hortikultura Tahun 2012. Directorate General of Horticulture, Agricultural Ministry of Indonesia. Jakarta, Indonesia.

Anwarudin, M.J.S., Apri, L.S., Aditia, M.K. \& Yusdar, H. 2015. The dynamics of production and chili price volatility: 
Strategy anticipate and development policy. Pengembangan Inovasi Pertanian 8(1): 33-42.

Astuti, R., Marimin, Machfud, Arkeman, Y., Poerwanto, R. \& Meuwissen, M. 2013. Risks and risks mitigations in the supply chain of mangosteen: A case study. Operations and Supply Chain Management 6(1): 11-25.

BPS (Central Bureau of Statistics in Indonesia). 2019. Dynamics table output (Output tabel dinamis). https://www.bps.go.id/ mod/exportData/exportPDF.php. Accessed on 21 October 2019.

BPS (Central Bureau of Statistics in Indonesia). 2017a. Provinsi Jawa Barat dalam Angka 2017. Statistics of Jawa Barat Province. ISSN 0215-2169.

BPS (Central Bureau of Statistics in Indonesia). 2017b. Tabel Dinamis Produksi Kentang dan Pisang Indonesia. https:// www.bps.go.id/. Accessed on 20 October 2017.

Bluman, A.G. 2009. Elementary Statistics: A Step by Step Approach. 7th edition. ISBN 978-0-07-353497-8. New York: McGraw - Hill.

Bozoglu, M. \& Ceyhan, V. 2007. Measuring the technical efficiency and exploring the inefficiency determinants of vegetable farms in Samsun Province, Turkey. Agricultural Systems 94: 649-656.

Chembezi, D.M. 1991. Modeling acreage response with risk consideration: The case of estate tobacco in Malawi. Agricultural Systems 36: 427-438.

Claessens, S. 2006. Access to financial services: A review of the issues and public policy objectives. The World Bank Research Observer 21(2): 207-240.

Erny, Darwanto, D.H., Masyhuri. \& Waluyati, L.R. 2019. Farmer's behavior towards Lembah Palu shallot farm risks in Central Sulawesi, Indonesia. EurAsian Journal of BioSciences 13: 931-936.

Gebrehiwot, T. \& Van der Veen, A. 2013. Farm level adaptation to climate change: The case of farmer's in the Ethiopian Highlands. Environmental Management 52: 29-44. DOI: 10.1007/s00267-013-0039-3.

Girabi, F. \& Mwakaje, A.E.G. 2013. Impact of microfinance on smallholder farm productivity in Tanzania: The case of Irambia District. Asian Economic and Financial Review 3(2): 227-242

Hamzah, A.A.I.Z., Abu Bakar, Z.H., Abdul Sani, N.F., Tan, J.K., Ahmad Damanhuri, M.H., Nor Aripin, K.N., Mohd Rani, M.D., Noh, N.A., Razali, R., Mohamad, M., Makpol, S., Mazlan, M., Abdul Hamid, H. \& Wan Ngah, W.Z. 2016. Relationship between education and cognitive performance among healthy Malay Adults. Sains Malaysiana 45(9): 1371-1379.

Hardaker, J.B., Lien, G., Anderson, J.R. \& Huirne, R.B.M. 2015. Coping with Risk in Agriculture: Applied Decision Analysis. Wallingford-UK: CABI Publishing.

Hariyani, N., Koestiono, D. \& Muhaimin, A.W. 2017. The risk level of production and price of red chili farming in Kediri Regency, East Java Province, Indonesia. Agricultural SocioEconomics Journal 17(02): 81-87.

Hartati, A. 2007. The effect of farmer's behavior on the risk of potato farming efficiency in Wonosobo District, Central Java. Agroland 14(3): 165-171.

Hasni. 2017. Tempting, opportunities for exporting horticultural products. Warta Pengkajian Perdagangan 1(13): 2-5.
Kaburuan, E.R., Jayadi, R. \& Harisno. 2019. A design of IoTbased monitoring system for intelligence indoor microclimate horticulture farming in Indonesia. Procedia Computer Science 157: 459-464.

Kurniati, D. 2015. Farmers' behavior towards the risk of soybean farming in South Jawai Subdistrict, Sambas District. Jurnal Social Economic of Agriculture 4(1): 32-36.

Lamprinopoulou, C., Tregear, A. \& Ness, M. 2006. Agrifood SMEs in Greece: The role of collective action. British Food Journal 108(8): 663-676.

Ling Hoon Leh, O., Mohamed Musthafa, S.N.A. \& Abdul Rasam, A.R. 2014. Urban environmental heath: Respiratory infection and urban factors in urban growth corridor of Petaling Jaya, Shah Alam and Klang, Malaysia. Sains Malaysiana 43(9): 1405-1414.

Ogurtsov, V.A., Van Asseldonk, M.A.P.M. \& Huirne, R.B.M. 2009. Purchase of catastrophe insurance by Dutch dairy and arable farmers. Applied Economic Perspectives and Policy 3: $143-162$.

Rachman, H.P.S. 1997. Aspek permintaan, penawaran dan tataniaga hortikultura di Indonesia. FAE 15: 1-2.

Rook, A.J., Dhanoa, M.S. \& Gill, M. 1990. Prediction of the voluntary intake of grass silages by beef cattle 2 Principal component and ridge regression analysis. Animal Production 50: 439-454.

Saha, A.A. 1994. Two-season agricultural household model of output and price uncertainty. Journal of Development Economics 45: 245-269.

Schipmann, C. \& Qaim, M. 2011. Supply chain differentiation, contract agriculture, and farmers' marketing preferences: The case of sweet paper in Thailand. Food Policy 36: 667677.

Suherman, Mega Sari, R. \& Soeyatno, R.F. 2017. The impact of the Upsus national program to the price risk of red chili in Indonesia. Advances in Intelligent Systems Research 149: $67-70$.

Slamet, A.S., Nakayasu, A. \& Ichikawa, M. 2017. Small-scale vegetable farmers' participation in modern retail market channels in Indonesia: The determinants of and effects on their income. Agriculture 7(11): 1-16.

Verbeek, M. 2004. A Guide to Modern Econometrics. 4th edition. London: John Wiley \& Sons, Ltd.

Wicaksono, E. 2014. The impact of agricultural credit on rice productivity. International Journal on Advanced Science Engineering Information Technology 4(5): 20-23.

Wulandari, E., Meuwissen, M., Karmana, M.H. \& Oude Lansink, A. 2017. Access to finance from different finance provider types: Farmer knowledge of the requirements. PloS ONE 12(9): e0179285.

Faculty of Agriculture

Universitas Padjadjaran

Jl. Raya Bandung-Sumedang km. 21

Jatinangor 45363

Indonesia

*Corresponding author; email: eliana.wulandari@unpad.ac.id

Received: 28 February 2019

Accepted: 10 November 2019 